\title{
Influential WoS indexed papers on Food Technology domain in 2015: An overview of the current influences of Food technology research
}

Houcemeddine Turki ${ }^{\mathrm{a}}$, Seyed Mohammad Jafar Jalali ${ }^{\mathrm{b}}$

${ }^{a}$ Faculty of Medicine of Sfax, University of Sfax, Sfax, Tunisia

${ }^{\mathrm{b}}$ Department of Information Technology Management, Allameh Tabataba'i University, Tehran, Iran

\begin{abstract}
In this research paper, we analyzed the $\mathrm{h}_{\mathrm{y}}$-core of Food technology Thomson Reuters Web of Science indexed papers for the year 2015 using Bibliometric and Scientometric techniques to obtain an overview about the main journals, institutions, authors and countries that influence the most Food technology research area nowadays. This study confirmed that the main papers that currently influences Food technology research are either new papers defining innovative techniques and findings or old papers that are mainly cited because they are considered as fundamental in the field by the Food technology research communities. It also proved a major current influence of the old highly cited researchers, of the specialized nationwide research institutes, of the journals with high impact factors that publish papers about all the aspects of Food technology research, and of the United States specifically University of Massachusetts Amherst on Food technology research.
\end{abstract}

Keywords: Influential papers, Web of Science, Food technology, Research Influences

\section{Introduction}

Food Technology research is the one explicitly dealing with the creation, adjustment or application of Chemical or Engineering techniques to analyze, modify or generate food patterns (Moraru, Panchapakesan, Huang, Takhistov, Sean, \& Kokini, 2003). It has become an important and influential field of research which can help ameliorate quality and easiness in production of foods and reducing their costs (Alston, Beddow, \& Pardey, 2009; Fan \& Pardey, 1997; Thompson \& Scoones, 2009; Heaton, 2001). That is why the first trials to assess the output quality, the practical effect and the usefulness of food science and technology research were not recent as there is a work that was written in 1948 about the issue (Fisher \& Yates, 1949). Nowadays, Food Technology Research Evaluation is still an ongoing research trend as $2.4 \%$ of the worldwide scientometric studies deal with Agricultural and Food Science (Gao, 2015). In fact, more interest is given to the evaluation of research productivity (Ravichandran \& Vijayakumar, 2015; Glänzel \& Veugelers, 2006; Van Raan \& Van Leeuwen, 2002) as well as the theoretical and practical effect of Food Technology Research worldwide and even by region (Fan \& Pardey, 1997; Alfaraz \& Calviño, 2004; Poornima, Surulinathi, Amsaveni, \& Vijayaragavan, 2011) or by journal (Vijay \& Raghavan, 2007; Gomathi, 2014; Zan \& Zan, 2014), to the detection of the significant trends (Ravichandran \& Vijayakumar, 2015), to analyze the behavior of the editors of Food technology journals in accepting papers for publication (Amat, 2007) and of the behavior of Food technology researchers in citing papers (Ravichandran \& Vijayakumar, 2015; Braun, Glänzel, \& Grupp, 1995), choosing topics (Eriksson, 1997) and establishing international or interdisciplinary research collaborations (Ponds, Van Oort, \& Frenken, 2007; Zhou, Zhong, \& Yu, 2013; Van Raan \& Van Leeuwen, 2002; Vijay \& Raghavan, 2007; Liu, Guns, Wei, \& Yin, 2013; Mazloumian, Helbing, Lozano, Light, \& Börner, 2013) and detection of Food technology research topics in need of proliferation (Calo-Mata, Arlindo, Boehme, de Miguel, 
Pascoal, \& Barros-Velazquez, 2008; Achanta \& Okos, 1996; Van Raan \& Van Leeuwen, 2002). Such works use basic Bibliometric and Scientometric Analysis methods as well as the analysis of word co-occurrence networks and citation networks to give a detailed overview about food technology research (Van Raan \& Van Leeuwen, 2002; Zhou, Zhong, \& Yu, 2013).

In the present study, we give a list of the WoS papers that had most influenced the ones published in the year of 2015 to give an overview about the current situation and main influences of Food Technology Research and to verify if the analysis of the metadata of the yearly highly cited papers of a topic gives an idea about the individuals, journals, institutions, and countries that influence the most that field with the same accuracy as the one of the analysis of the metadata of all the papers about that field of interest.

\section{Methods}

\section{Paper Selection}

Using Thomson Reuters Web of Science Database and Website (Thomson Reuters, 2016), All the Literature about Food Science in all the WoS collections is gathered and their citation reports are exported as XLS files. The papers are then classified according to their number of WoS received citations in 2015 using Microsoft Office Excel 2007 (Microsoft Corporation, 2007) and the works that are not related to food technology research are then manually eliminated.

Analyzing all the papers requires advanced computer definitions (Grivel, Polanco, \& Kaplan, 1997). That is why the analysis has been limited to a significant number of papers. Nowadays, it has been proved that the Hirsch core of a scientist (Cabrerizo, Alonso, Herrera-Viedma, \& Herrera, 2010; Hirsch, 2005; Glänzel, 2008) or a topic (Banks, 2006) can reflect the characteristics of all the set of the papers from which it has been derived because the papers of the h-core are generally highly cited and consequently they are very likely to be cited in the other works of their original set. Similarly, the $\mathrm{h}_{\mathrm{y}}$-core of a set of papers can represent the current trends of that set of papers . In fact, this $h_{y}$-core is the set of papers having a number of received citations in year $\mathrm{y}$ that is superior or equal to the $\mathrm{h}_{\mathrm{y}}$-index or the yearly $\mathrm{h}$-index (Cabrerizo, Alonso, Herrera-Viedma, \& Herrera, 2010; Sidiropoulos, Katsaros, \& Manolopoulos, 2007), defined as $h_{y}$ such that $h_{y}$ of the papers of the original set have each $h_{y}$ or more citations received in year $y$ and also the other papers of the original set have each $h_{y}$ or less citations received in year y (Sidiropoulos, Katsaros, \& Manolopoulos, 2007). As the number of the received citations of these $h_{y}$-core papers in a given year $y$ is significant and the number of papers issued in the same year $y$ for a topic is limited, the papers of the $\mathrm{h}_{\mathrm{y}}$-core would be cited in quite all the works of the year y and would consequently represent the research trends and influences of the field of the initial set of papers in the year $y$.

Therefore the $\mathrm{h}_{\mathrm{y}}$-index of the WoS indexed Food technology related papers for the year 2015 has been calculated through WoS website and the $h_{y}$-core of the papers has been considered to study the current influences in Food Chemistry research. 
The data about each research paper including titles, authors, author affiliations, journals, and years of publication have been retrieved using Thomson Reuters Web of Science website as a plain text.

\section{Data Processing}

To study the influence of authors, countries, names, journals and papers in Food technology research in 2015, HistCite has been used to retrieve the lists of the most published authors, countries, institutions and journals as well as the citation relationships in the set from the obtained plain text (Thomson Reuters, 2012), Developed by Eugene Garfield (Garfield E. , 2009), the software has proved to be efficient in doing such retrievals to study other scientific fields (Lucio-Arias \& Leydesdorff, 2008; Bornmann \& Marx, 2012).

\section{Results and Discussion}

The obtained set of WoS influential papers about Food technology research in 2015 involves 46 papers (Appendix A). All of them were written in English and included in Web of Science Core Collection. This language bias is explained by the lack of coverage of the scientfic literature written in languages other than English in WoS databases (Van Leeuwen, Moed, Tijssen, Visser, \& Van Raan, 2001).

As shown in Fig. 1, most of the papers are unsurprisingly published after 2006 and evocating new and breakthrough findings in Food technology research. However, there are some papers that are still highly cited in 2015 even if there are considerably old. This is mainly explained by the fact that these papers, or rather Citation Classics, have added a fundamental theory in the field of Food technology (Abt, 1998; Garfield, 1986).

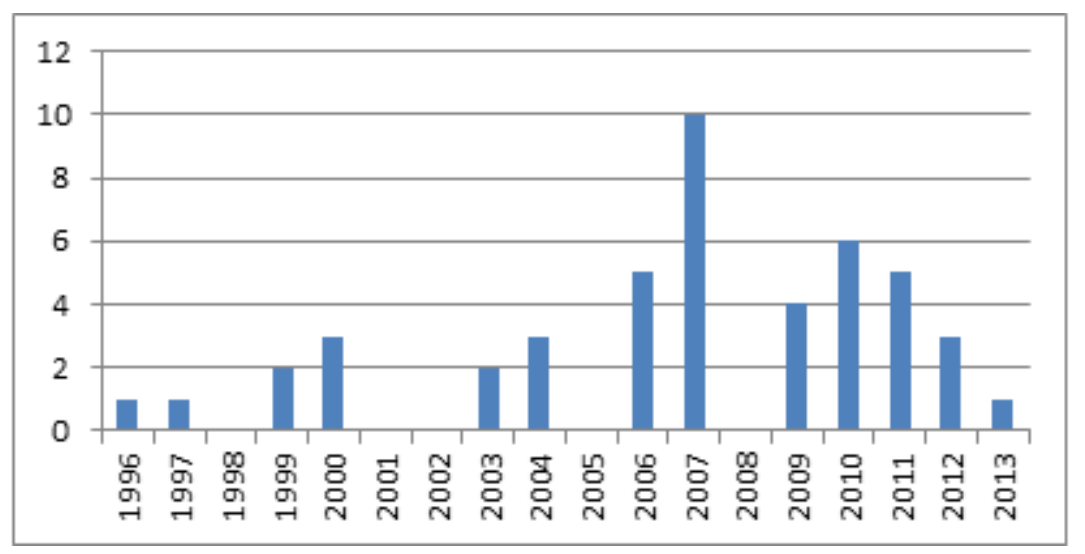

Fig. 1: Repartition of the papers according to years of publication

In fact, these papers have even been references for some of the more recent highly cited papers in 2015 as shown in Fig. 2. Such papers can remain highly cited even after decades of their creation (Abt, 1998). 


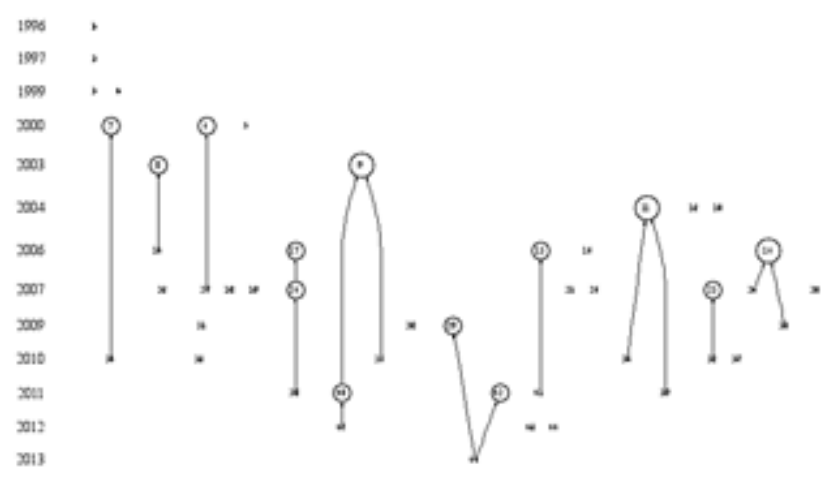

Fig. 2: Direct citation network of local citations for the 46 influential papers

As the types of the 46 documents are retrieved, it is seen that 30 of the papers are reviews (65.217\%), 16 are articles $(34.783 \%)$ and 7 are proceedings papers $(15.217 \%)$. This is mainly explained by the important tendency of the scientists to cite the works of synthesis that review and evaluate the main research works about Food Technology as they involve all the recent advances in the field (Bornmann \& Daniel, 2008; Case \& Higgins, 2000).

With identification of the leading authors, it is clear that David Julian McClements from University of Massachusetts Amherst (United States) is the most influential author of the set with 4 publications followed by Eric Andrew Decker from University of Massachusetts Amherst with 3 publications and Ibrahim M Banat from University of Ulster (United Kingdom), Hannu Korhonen from MTT Agrifood Research Finland (Finland) and Jochen Weiss from University of Massachusetts Amherst with 2 publications. This fact is confirmed when calculating their $\mathrm{h}$-indices using Google Scholar as it is seen that $\mathrm{h}>=55$ proving that these scientists are in the main reference scientists in this field of research (Hirsch, An index to quantify an individual's scientific research output, 2005). It is clear that the works of these scientists had even ameliorated the influence of their institutions on the field as they are among the eight best published institutions in the set of 46 papers as shown in Bold in Table 1. The advantage of the University of Massachusetts Amherst is mainly explained by the fruitful collaboration between McClements, Decker and Weiss (McClements, Decker, Park, \& Weiss, 2009). In fact, it has been confirmed in many studies that multiauthored papers can have more effect than papers written by a single author mainly when all the collaborating authors are important scientists (Hirsch, 2010; Van Hooydonk, 1997; Tscharntke, Hochberg, Rand, Resh, \& Krauss, 2007; Oromaner, 1975).

\begin{tabular}{|c|c|c|}
\hline Institution & Country & Paper \\
\hline University of Massachusetts Amherst & $\begin{array}{c}\text { United } \\
\text { States }\end{array}$ & 4 \\
\hline $\begin{array}{c}\text { Consejo Superior de investigaciones } \\
\text { cientificas CSIC }\end{array}$ & Spain & 3 \\
\hline Agriculture Agri Food Canada & Canada & 2 \\
\hline
\end{tabular}




\begin{tabular}{|c|c|c|}
\hline $\begin{array}{c}\text { Council of Scientific Industrial Research } \\
\text { CSIR }\end{array}$ & India & 2 \\
\hline $\begin{array}{c}\text { Institut National de la Recherche } \\
\text { Agronomique }\end{array}$ & France & 2 \\
\hline Monash University & Australia & 2 \\
\hline University of Ulster & Finland & 2 \\
\hline $\begin{array}{c}\text { United } \\
\text { Kingdom }\end{array}$ & 2 \\
\hline
\end{tabular}

Table 1: Repartition of the papers according to their issuing institutions

Quite all the remaining institutions are national research institutes or structure about Food technology as shown in Italics in Table 1 and this is evident as such institutions are co-editing all the Food Technology papers of the country they exist in (Picard, Darmon, \& Pradoura, 1990).

When seeing the list of most published countries, it is clear that the countries of the eight ranked institutions are featured as shown in Bold in Table 2.

\begin{tabular}{|c|c|}
\hline Country & Papers \\
\hline $\begin{array}{c}\text { United } \\
\text { States }\end{array}$ & 11 \\
\hline Germany & 5 \\
\hline Spain & 5 \\
\hline $\begin{array}{c}\text { United } \\
\text { Kingdom }\end{array}$ & 4 \\
\hline India & 4 \\
\hline Australia & 3 \\
\hline France & 3 \\
\hline Ireland & 3 \\
\hline Finland & 2 \\
\hline Netherlands & 2 \\
\hline Canada & 2 \\
\hline
\end{tabular}

Table 2: Repartition of the papers according to their issuing countries

The existence of other countries in the ranking and by that their influence in Food Technology research is mainly explained by the existence of nationwide leading food science research institutes that monitor and adjust the quality of Food technology research in these countries (Picard, Darmon, \& Pradoura, 1990; Lafferty, Commins, \& Walsh, 1999) or by the 
involvement of these countries in these influential papers through international collaborations (Aksnes, 2003; Zhou, Zhong, \& Yu, 2013). In fact, both facts are common in the publication of highly cited papers (Picard, Darmon, \& Pradoura, 1990; Aksnes, 2003). The existence of these countries can also be explained by their history and weight in Food technology research. In fact, all the countries showed in the Table are cited in previous studies as the most productive and cited countries as well as the oldest ones in Food technology research (Fisher \& Yates, 1949; Braun, Glänzel, \& Grupp, 1995; Scimago Lab, 2015; Surwase, Mohan, Kademani, \& Bhanumurthy, 2014; Van Raan \& Van Leeuwen, 2002).

As for the most influential journals in 2015, they are the main specialized journals having an $\mathrm{IF}>=2.4$ that publish original researches contributing to the advancement of all aspects of Food Technology as shown in Table 3. Journals like Meat Science that are contributing to a particular aspect of Food technology do not exist even if they have important Impact Factors (Thomson Reuters, 2015).

\begin{tabular}{|c|c|c|}
\hline Journal & Papers & $\begin{array}{c}2014 \text { Impact } \\
\text { Factor } \\
\text { Thomson } \\
\text { Reuters, } \\
2015)\end{array}$ \\
\hline $\begin{array}{c}\text { TRENDS IN FOOD SCIENCE AND } \\
\text { TECHNOLOGY }\end{array}$ & 6 & 4.651 \\
\hline $\begin{array}{c}\text { INTERNATIONAL JOURNAL OF } \\
\text { FOOD MICROBIOLOGY }\end{array}$ & 4 & 3.082 \\
\hline $\begin{array}{c}\text { CRITICAL REVIEWS IN FOOD } \\
\text { SCIENCE AND NUTRITION }\end{array}$ & 3 & 5.176 \\
\hline $\begin{array}{c}\text { APPLIED MICROBIOLOGY AND } \\
\text { BIOTECHNOLOGY }\end{array}$ & 2 & 3.337 \\
\hline FOOD CHEMISTRY & 2 & 3.391 \\
\hline $\begin{array}{c}\text { LWT FOOD SCIENCE AND } \\
\text { TECHNOLOGY }\end{array}$ & 2 & 2.416 \\
\hline
\end{tabular}

Table 3: Repartition of the papers according to their issuing journals

This is evident because a research about Meat Technology can only be used in researches about that particular field of Food technology. However, general developments and amelioration of techniques in Food technology can be used in all aspects of Food technology including Meat Research (Bornmann \& Daniel, 2008).

\section{Conclusion}

The present study provides a snapshot of bibliometric and scientometric methods to examine the current influences of the research driven by Food Technology specialists. Totally 46 documents have been selected as the most pioneer ones. The institutions, journals, scientists and countries which were the main sources of influential contributions have been recognized using bibliometric methods. However, this research has been faced with some limitations which can also provide future research for other scholars. Firstly, our method has just been applied on WoS core collection dataset. The future research can be applied on other wellknown datasets such as Scopus. Also, secondly, the future scholars can integrate Scopus and WoS databases to compare the results with current study. The obtained results of the paper 
will especially be of interest to Food Technology research community how research into Food Technology field is transforming and for food industry professionals to figure out their international research outreaches, while it is also worthwhile to mention that the methods that has been used in this paper will be of attentiveness to the scientometric scholars

\section{Acknowledgements}

The findings shown in this paper were first presented in the Fourth Agri-Food Scientific Days of the AMIAA (JSAA'2016) held from 20 to 23 March 2016 in Sousse, Tunisia. We have to thank the AMIAA administrators and members and mainly Dr. Souhail Besbes and Dr. Hamadi Attia from the University of Sfax as well as all the reviewers of the work for their helpful discussions and comments that led to the amelioration of the final output of the paper. We have also to thank CNUDST for providing free and full access to Thomson Reuters Web of Science website and database.

\section{References}

Abt, H. A. (1998). Why some papers have long citation lifetimes. Nature, 395, 756-757.

Achanta, S., \& Okos, M. R. (1996). Predicting the quality of dehydrated foods and biopolymers — research needs and opportunities. Drying Technology, 14 (6), 1329-1368.

Aksnes, D. W. (2003). Characteristics of highly cited papers. Research Evaluation, 12 (3), 159-170.

Alfaraz, P., \& Calviño, A. (2004). Bibliometric study on food science and technology: Scientific production in Iberian-American countries (1991-2000). Scientometrics, 61 (1), 89102.

Alston, J. M., Beddow, J. M., \& Pardey, P. G. (2009). Agricultural research, productivity, and food prices in the long run. Science, 325 (5945), 1209-1210.

Amat, C. (2007). Editorial and publication delay of papers submitted to 14 selected Food Research journals. Influence of online posting. Scientometrics, 74 (3), 379-389.

Banks, M. G. (2006). An extension of the Hirsch index: Indexing scientific topics and compounds. Scientometrics, 69 (1), 161-168.

Bornmann, L., \& Daniel, H. D. (2008). What do citation counts measure? A review of studies on citing behavior. Journal of Documentation, 64 (1), 45-80.

Bornmann, L., \& Marx, W. (2012). HistCite analysis of papers constituting the $\mathrm{h}$ index research front. Journal of Informetrics, 6 (2), 285-288.

Braun, T., Glänzel, W., \& Grupp, H. (1995). The scientometric weight of 50 nations in 27 science areas, 1989-1993. Part II. Life sciences. Scientometrics, 34 (2), 207-237. 
Cabrerizo, F. J., Alonso, S., Herrera-Viedma, E., \& Herrera, F. (2010). q2-Index: Quantitative and qualitative evaluation based on the number and impact of papers in the Hirsch core. Journal of Informetrics, 4 (1), 23-28.

Calo-Mata, P., Arlindo, S., Boehme, K., de Miguel, T., Pascoal, A., \& Barros-Velazquez, J. (2008). Current applications and future trends of lactic acid bacteria and their bacteriocins for the biopreservation of aquatic food products. Food and Bioprocess Technology, 1 (1), 43-63.

Case, D. O., \& Higgins, G. M. (2000). How can we investigate citation behavior? A study of reasons for citing literature in communication. Journal of the American Society for Information Science, 51 (7), 635-645.

Eriksson, E. D. (1997). Topics in Food Science and Nutrition March 1997: 65-75. Nutrition reviews, 55 (3), 65 .

Fan, S., \& Pardey, P. G. (1997). Research, productivity, and output growth in Chinese agriculture. Journal of Development Economics, 53 (1), 115-137.

Fisher, R. A., \& Yates, F. (1949). Statistical tables for biological, agricultural and medical research (3 ed.).

Gao, S. (2015). Towards a frontier of spatial scientometric studies by SONG Gao with Martin Vesely as coordinator. ACM SIGWEB Newsletter (Spring), 5.

Garfield, E. (1986). Do Nobel-Prize Winners Write Citation-classics. Current Contents, 23, 38.

Garfield, E. (2009). From the science of science to Scientometrics visualizing the history of science with HistCite software. Journal of Informetrics, 3 (3), 173-179.

Glänzel, W. (2008). What are your best papers? ISSI Newsletter, 4 (4), 64-67.

Glänzel, W., \& Veugelers, R. (2006). Science for wine: A bibliometric assessment of wine and grape research for wine-producing and consuming countries. American journal of enology and viticulture, 57 (1), 23-32.

Gomathi, P. (2014). Scientometric Dimensions of Food Science and Technology Research from 2007 to 2012. International Journal of Pharmaceutical \& Biological Archive, 5 (2).

Grivel, L., Polanco, X., \& Kaplan, A. (1997). A computer system for big scientometrics at the age of the World Wide Web. Scientometrics, 40 (3), 493-506.

Heaton, S. (2001). Organic farming, food quality and human health. Soil Association.

Hirsch, J. E. (2010). An index to quantify an individual's scientific research output that takes into account the effect of multiple coauthorship?. Scientometrics, 85 (3), 741-754. 
Hirsch, J. E. (2005). An index to quantify an individual's scientific research output. Proceedings of the National academy of Sciences of the United States of America, 102 (46), 16569-16572.

Liu, Y., Guns, R., Wei, W., \& Yin, J. (2013). Genetically Modified Food research in China: Interactions between authors from Social sciences and Natural sciences. Proceedings of the 14th International Society of Scientometrics and Informetrics Conference, I, pp. 819-830. Vienna, Austria.

Lucio-Arias, D., \& Leydesdorff, L. (2008). Main-path analysis and path-dependent transitions in HistCite ${ }^{\mathrm{TM}}$-based historiograms. Journal of the American Society for Information Science and Technology, 59 (12), 1948-1962.

Mazloumian, A., Helbing, D., Lozano, S., Light, R. P., \& Börner, K. (2013). Global multilevel analysis of the 'Scientific Food Web'. Scientific reports, 3 (1167).

McClements, D. J., Decker, E. A., Park, Y., \& Weiss, J. (2009). Structural design principles for delivery of bioactive components in nutraceuticals and functional foods. Critical Reviews in Food Science and Nutrition, 49 (6), 577-606.

Microsoft Corporation. (2007). Microsoft Office Excel 2007.

Moraru, C. I., Panchapakesan, C. P., Huang, Q., Takhistov, P., Sean, L., \& Kokini, J. L. (2003). Nanotechnology: a new frontier in food science. Food Technology, 57 (12), 24-29.

Oromaner, M. (1975). Collaboration and impact: the career of multi-authored publications. Social Science Information, 14 (1), 147-155.

Picard, J. F., Darmon, G., \& Pradoura, E. (1990). La république des savants: La recherche française et le CNRS. Flammarion.

Ponds, R., Van Oort, F., \& Frenken, K. (2007). The geographical and institutional proximity of research collaboration. Papers in regional science, 86 (3), 423-443.

Poornima, A., Surulinathi, M., Amsaveni, N., \& Vijayaragavan, M. (2011). Mapping the Indian research productivity of food science and technology: A scientometric analysis. Food Biology, 1 (1).

Ravichandran, P., \& Vijayakumar, P. (2015). Food Chemistry: A Bibliometric Analysis of Publications Output during 2004-2013. Indian Journal of Science, 21 (72), 231-240.

Scimago Lab. (2015). Country Rankings in Food Science. Retrieved from SJR:

http://www.scimagojr.com/countryrank.php?area=0\&category=1106\&region=all\&year=all\&o $\underline{\text { rder}=i t \& \min =0 \& \min \_ \text {type }=\text { it }}$

Sidiropoulos, A., Katsaros, D., \& Manolopoulos, Y. (2007). Generalized Hirsch h-index for disclosing latent facts in citation networks. Scientometrics, 72 (2), 253-280. 
Surwase, G., Mohan, L., Kademani, B. S., \& Bhanumurthy, K. (2014). Research Trends on Food Preservation: A Scientometric Analysis. DESIDOC Journal of Library \& Information Technology, 34 (3).

Thompson, J., \& Scoones, I. (2009). Addressing the dynamics of agri-food systems: an emerging agenda for social science research. Environmental science \& policy, 12 (4), 386397.

Thomson Reuters. (2012). HistCite.

Thomson Reuters. (2015). Journal Citation Report.

Thomson Reuters. (2016). Web of Science.

Tscharntke, T., Hochberg, M. E., Rand, T. A., Resh, V. H., \& Krauss, J. (2007). Author sequence and credit for contributions in multiauthored publications. PLoS Biology, 5 (1), e18.

Van Hooydonk, G. (1997). Fractional counting of multiauthored publications: Consequences for the impact of authors. Journal of the American Society for Information Science, 48 (10), 944-945.

Van Leeuwen, T., Moed, H., Tijssen, R., Visser, M., \& Van Raan, A. (2001). Language biases in the coverage of the Science Citation Index and its consequences for international comparisons of national research performance. Scientometrics, 51(1), 335-346.

Van Raan, A. F., \& Van Leeuwen, T. N. (2002). Assessment of the scientific basis of interdisciplinary, applied research: application of bibliometric methods in nutrition and food research. Research Policy, 31 (4), 611-632.

Vijay, K. R., \& Raghavan, I. (2007). Journal of Food Science and Technology: a bibliometric study. Annals of Library and Information Studies, 54 (4), 207.

Zan, B. U., \& Zan, N. (2014). A Collaboration Analysis Study of Food Chemistry Journal. International Journal of Engineering and Innovative Technology, 4 (1).

Zhou, P., Zhong, Y., \& Yu, M. (2013). A bibliometric investigation on China-UK collaboration in food and agriculture. Scientometrics, 97 (2), 267-285.

\section{Appendix A: The list of WoS influential papers in 2015}

\begin{tabular}{|l|l|l|r|r|}
\hline Title & Authors & Source Title & $\begin{array}{l}\text { Publicatio } \\
\text { n Year }\end{array}$ & $\begin{array}{l}\text { 2015 } \\
\text { Citations }\end{array}$ \\
\hline $\begin{array}{l}\text { Cyclodextrins and their } \\
\text { uses: a review }\end{array}$ & Del Valle, EMM & $\begin{array}{l}\text { PROCESS } \\
\text { BIOCHEMISTRY }\end{array}$ & 2004 & 141 \\
\hline $\begin{array}{l}\text { Performance comparison } \\
\text { of benchtop high- } \\
\text { throughput sequencing } \\
\text { platforms }\end{array}$ & $\begin{array}{l}\text { Loman, Nicholas } \\
\text { J.; Misra, Raju V.; } \\
\text { Dallman, Timothy } \\
\text { J.; Constantinidou, } \\
\text { Chrystala; Gharbia, } \\
\text { Saheer E.; Wain, }\end{array}$ & $\begin{array}{l}\text { NATURE } \\
\text { YIOTECHNOLOG }\end{array}$ & & \\
\hline
\end{tabular}




\begin{tabular}{|c|c|c|c|c|}
\hline & $\begin{array}{l}\text { John; Pallen, Mark } \\
\text { J. }\end{array}$ & & & \\
\hline $\begin{array}{l}\text { Applications of } \\
\text { ultrasound in food } \\
\text { technology: Processing, } \\
\text { preservation and } \\
\text { extraction }\end{array}$ & $\begin{array}{l}\text { Chemat, Farid; } \\
\text { Zill-e-Huma; } \\
\text { Khan, Muhammed } \\
\text { Kamran }\end{array}$ & $\begin{array}{l}\text { ULTRASONICS } \\
\text { SONOCHEMISTR } \\
\text { Y }\end{array}$ & 2011 & 113 \\
\hline $\begin{array}{l}\text { Industrial applications of } \\
\text { microbial lipases }\end{array}$ & $\begin{array}{l}\text { Hasan, Fariha; } \\
\text { Shah, Aamer Ali; } \\
\text { Hameed, Abdul }\end{array}$ & $\begin{array}{l}\text { ENZYME AND } \\
\text { MICROBIAL } \\
\text { TECHNOLOGY } \\
\end{array}$ & 2006 & 103 \\
\hline $\begin{array}{l}\text { Applications of } \\
\text { nanotechnology in food } \\
\text { packaging and food } \\
\text { safety: Barrier materials, } \\
\text { antimicrobials and } \\
\text { sensors }\end{array}$ & $\begin{array}{l}\text { Duncan, Timothy } \\
\text { V. }\end{array}$ & $\begin{array}{l}\text { JOURNAL OF } \\
\text { COLLOID AND } \\
\text { INTERFACE } \\
\text { SCIENCE }\end{array}$ & 2011 & 86 \\
\hline $\begin{array}{l}\text { Bio-nanocomposites for } \\
\text { food packaging } \\
\text { applications }\end{array}$ & $\begin{array}{l}\text { Rhim, Jong-Whan; } \\
\text { Park, Hwan-Man; } \\
\text { Ha, Chang-Sik }\end{array}$ & $\begin{array}{l}\text { PROGRESS IN } \\
\text { POLYMER } \\
\text { SCIENCE }\end{array}$ & 2013 & 81 \\
\hline $\begin{array}{l}\text { An overview of } \\
\text { foodborne pathogen } \\
\text { detection: In the } \\
\text { perspective of } \\
\text { biosensors }\end{array}$ & $\begin{array}{l}\text { Velusamy, } \\
\text { Vijayalakshmi; } \\
\text { Arshak, Khalil; } \\
\text { Korostynska, Olga; } \\
\text { Oliwa, Kamila; } \\
\text { Adley, Catherine }\end{array}$ & $\begin{array}{l}\text { BIOTECHNOLOG } \\
\text { Y ADVANCES }\end{array}$ & 2010 & 79 \\
\hline $\begin{array}{l}\text { Bioactive peptides: } \\
\text { Production and } \\
\text { functionality }\end{array}$ & $\begin{array}{l}\text { Korhonen, H; } \\
\text { Pihlanto, A }\end{array}$ & $\begin{array}{l}\text { INTERNATIONA } \\
\text { L DAIRY } \\
\text { JOURNAL } \\
\end{array}$ & 2006 & 76 \\
\hline $\begin{array}{l}\text { Perspectives for chitosan } \\
\text { based antimicrobial } \\
\text { films in food } \\
\text { applications }\end{array}$ & $\begin{array}{l}\text { Dutta, P. K.; } \\
\text { Tripathi, Shipra; } \\
\text { Mehrotra, G. K.; } \\
\text { Dutta, Joydeep } \\
\end{array}$ & $\begin{array}{l}\text { FOOD } \\
\text { CHEMISTRY }\end{array}$ & 2009 & 76 \\
\hline $\begin{array}{l}\text { Hyperspectral imaging - } \\
\text { an emerging process } \\
\text { analytical tool for food } \\
\text { quality and safety } \\
\text { control }\end{array}$ & $\begin{array}{l}\text { Gowen, A. A.; } \\
\text { O'Donnell, C. P.; } \\
\text { Cullen, P. J.; } \\
\text { Downey, G.; Frias, } \\
\text { J. M. }\end{array}$ & $\begin{array}{l}\text { TRENDS IN } \\
\text { FOOD SCIENCE } \\
\& \text { TECHNOLOGY }\end{array}$ & 2007 & 75 \\
\hline $\begin{array}{l}\text { Microbial biosurfactants } \\
\text { production, applications } \\
\text { and future potential }\end{array}$ & $\begin{array}{l}\text { Banat, Ibrahim M.; } \\
\text { Franzetti, Andrea; } \\
\text { Gandolfi, Isabella; } \\
\text { Bestetti, } \\
\text { Giuseppina; } \\
\text { Martinotti, Maria } \\
\text { G.; Fracchia, } \\
\text { Letizia; Smyth, } \\
\text { Thomas J.; } \\
\text { Marchant, Roger }\end{array}$ & $\begin{array}{l}\text { APPLIED } \\
\text { MICROBIOLOGY } \\
\text { AND } \\
\text { BIOTECHNOLOG } \\
\text { Y }\end{array}$ & 2010 & 73 \\
\hline $\begin{array}{l}\text { Bacteriocin-based } \\
\text { strategies for food } \\
\text { biopreservation }\end{array}$ & $\begin{array}{l}\text { Galvez, Antonio; } \\
\text { Abriouel, Hikmate; } \\
\text { Lopez, Rosario }\end{array}$ & $\begin{array}{l}\text { INTERNATIONA } \\
\text { L JOURNAL OF } \\
\text { FOOD } \\
\end{array}$ & 2007 & 71 \\
\hline
\end{tabular}




\begin{tabular}{|c|c|c|c|c|}
\hline & $\begin{array}{l}\text { Lucas; Ben Omar, } \\
\text { Nabil }\end{array}$ & MICROBIOLOGY & & \\
\hline $\begin{array}{l}\text { Pathogen detection: A } \\
\text { perspective of traditional } \\
\text { methods and biosensors }\end{array}$ & $\begin{array}{l}\text { Lazcka, Olivier; } \\
\text { Del Campo, F. } \\
\text { Javier; Munoz, F. } \\
\text { Xavier }\end{array}$ & $\begin{array}{l}\text { BIOSENSORS \& } \\
\text { BIOELECTRONI } \\
\text { CS }\end{array}$ & 2007 & 69 \\
\hline $\begin{array}{l}\text { Engineering the } \\
\text { provitamin A (beta- } \\
\text { carotene) biosynthetic } \\
\text { pathway into } \\
\text { (carotenoid-free) rice } \\
\text { endosperm }\end{array}$ & $\begin{array}{l}\text { Ye, XD; Al-Babili, } \\
\text { S; Kloti, A; Zhang, } \\
\text { J; Lucca, P; Beyer, } \\
\text { P; Potrykus, I }\end{array}$ & SCIENCE & 2000 & 67 \\
\hline $\begin{array}{l}\text { Food-derived peptides } \\
\text { with biological activity: } \\
\text { from research to food } \\
\text { applications }\end{array}$ & $\begin{array}{l}\text { Hartmann, Rainer; } \\
\text { Meisel, Hans }\end{array}$ & $\begin{array}{l}\text { CURRENT } \\
\text { OPINION IN } \\
\text { BIOTECHNOLOG } \\
\text { Y } \\
\end{array}$ & 2007 & 62 \\
\hline $\begin{array}{l}\text { Formation, stability and } \\
\text { properties of multilayer } \\
\text { emulsions for } \\
\text { application in the food } \\
\text { industry }\end{array}$ & $\begin{array}{l}\text { Guzey, Demet; } \\
\text { McClements, D. } \\
\text { Julian }\end{array}$ & $\begin{array}{l}\text { ADVANCES IN } \\
\text { COLLOID AND } \\
\text { INTERFACE } \\
\text { SCIENCE }\end{array}$ & 2006 & 62 \\
\hline $\begin{array}{l}\text { Potential commercial } \\
\text { applications of microbial } \\
\text { surfactants }\end{array}$ & $\begin{array}{l}\text { Banat, IM; } \\
\text { Makkar, RS; } \\
\text { Cameotra, SS }\end{array}$ & $\begin{array}{l}\text { APPLIED } \\
\text { MICROBIOLOGY } \\
\text { AND } \\
\text { BIOTECHNOLOG } \\
\text { Y } \\
\end{array}$ & 2000 & 59 \\
\hline $\begin{array}{l}\text { Sub- and supercritical } \\
\text { fluid extraction of } \\
\text { functional ingredients } \\
\text { from different natural } \\
\text { sources: Plants, food-by- } \\
\text { products, algae and } \\
\text { microalgae - A review }\end{array}$ & $\begin{array}{l}\text { Herrero, M; } \\
\text { Cifuentes, A; } \\
\text { Ibanez, E }\end{array}$ & $\begin{array}{l}\text { FOOD } \\
\text { CHEMISTRY }\end{array}$ & 2006 & 59 \\
\hline $\begin{array}{l}\text { A perspective on paper- } \\
\text { based microfluidics: } \\
\text { Current status and future } \\
\text { trends }\end{array}$ & $\begin{array}{l}\text { Li, Xu; Ballerini, } \\
\text { David R.; Shen, } \\
\text { Wei }\end{array}$ & $\begin{array}{l}\text { BIOMICROFLUI } \\
\text { DICS }\end{array}$ & 2012 & 59 \\
\hline $\begin{array}{l}\text { Microencapsulation: } \\
\text { industrial appraisal of } \\
\text { existing technologies } \\
\text { and trends }\end{array}$ & Gouin, $\mathrm{S}$ & $\begin{array}{l}\text { TRENDS IN } \\
\text { FOOD SCIENCE } \\
\& \text { TECHNOLOGY }\end{array}$ & 2004 & 57 \\
\hline $\begin{array}{l}\text { Opportunities and } \\
\text { challenges in high } \\
\text { pressure processing of } \\
\text { foods }\end{array}$ & $\begin{array}{l}\text { Rastogi, N. K.; } \\
\text { Raghavarao, K. S. } \\
\text { M. S.; } \\
\text { Balasubramaniam, } \\
\text { V. M.; Niranjan, } \\
\text { K.; Knorr, D. }\end{array}$ & $\begin{array}{l}\text { CRITICAL } \\
\text { REVIEWS IN } \\
\text { FOOD SCIENCE } \\
\text { AND NUTRITION }\end{array}$ & 2007 & 57 \\
\hline $\begin{array}{l}\text { Significance of biogenic } \\
\text { amines to food safety } \\
\text { and human health }\end{array}$ & Shalaby, AR & $\begin{array}{l}\text { FOOD } \\
\text { RESEARCH } \\
\text { INTERNATIONA }\end{array}$ & 1996 & 55 \\
\hline
\end{tabular}




\begin{tabular}{|c|c|c|c|c|}
\hline & & $\mathrm{L}$ & & \\
\hline $\begin{array}{l}\text { Characterisation of } \\
\text { structure-dependent } \\
\text { functional properties of } \\
\text { lignin with infrared } \\
\text { spectroscopy }\end{array}$ & $\begin{array}{l}\text { Boeriu, CG; Bravo, } \\
\text { D; Gosselink, RJA; } \\
\text { van Dam, JEG }\end{array}$ & $\begin{array}{l}\text { INDUSTRIAL } \\
\text { CROPS AND } \\
\text { PRODUCTS }\end{array}$ & 2004 & 55 \\
\hline $\begin{array}{l}\text { Electrodialysis, a mature } \\
\text { technology with a } \\
\text { multitude of new } \\
\text { applications }\end{array}$ & Strathmann, H. & DESALINATION & 2010 & 55 \\
\hline $\begin{array}{l}\text { Lactic acid: recent } \\
\text { advances in products, } \\
\text { processes and } \\
\text { technologies - a review }\end{array}$ & $\begin{array}{l}\text { Datta, Rathin; } \\
\text { Henry, Michael }\end{array}$ & $\begin{array}{l}\text { JOURNAL OF } \\
\text { CHEMICAL } \\
\text { TECHNOLOGY } \\
\text { AND } \\
\text { BIOTECHNOLOG } \\
\text { Y } \\
\end{array}$ & 2006 & 54 \\
\hline $\begin{array}{l}\text { Structural Design } \\
\text { Principles for Delivery } \\
\text { of Bioactive } \\
\text { Components in } \\
\text { Nutraceuticals and } \\
\text { Functional Foods }\end{array}$ & $\begin{array}{l}\text { McClements, } \\
\text { David Julian; } \\
\text { Decker, Eric } \\
\text { Andrew; Park, } \\
\text { Yeonhwa; Weiss, } \\
\text { Jochen } \\
\end{array}$ & $\begin{array}{l}\text { CRITICAL } \\
\text { REVIEWS IN } \\
\text { FOOD SCIENCE } \\
\text { AND NUTRITION }\end{array}$ & 2009 & 54 \\
\hline $\begin{array}{l}\text { Chemistry and uses of } \\
\text { pectin - A review }\end{array}$ & $\begin{array}{l}\text { Thakur, BR; Singh, } \\
\text { RK; Handa, AK }\end{array}$ & $\begin{array}{l}\text { CRITICAL } \\
\text { REVIEWS IN } \\
\text { FOOD SCIENCE } \\
\text { AND NUTRITION }\end{array}$ & 1997 & 53 \\
\hline $\begin{array}{l}\text { Inactivation of microbes } \\
\text { using ultrasound: a } \\
\text { review }\end{array}$ & $\begin{array}{l}\text { Piyasena, P; } \\
\text { Mohareb, E; } \\
\text { McKellar, RC }\end{array}$ & $\begin{array}{l}\text { INTERNATIONA } \\
\text { L JOURNAL OF } \\
\text { FOOD } \\
\text { MICROBIOLOGY }\end{array}$ & 2003 & 53 \\
\hline $\begin{array}{l}\text { Recovery of high added- } \\
\text { value components from } \\
\text { food wastes: } \\
\text { Conventional, emerging } \\
\text { technologies and } \\
\text { commercialized } \\
\text { applications }\end{array}$ & $\begin{array}{l}\text { Galanakis, Charis } \\
\text { M. }\end{array}$ & $\begin{array}{l}\text { TRENDS IN } \\
\text { FOOD SCIENCE } \\
\& \text { TECHNOLOGY }\end{array}$ & 2012 & 53 \\
\hline $\begin{array}{l}\text { Bioprocess engineering } \\
\text { of microalgae to produce } \\
\text { a variety of consumer } \\
\text { products }\end{array}$ & $\begin{array}{l}\text { Harun, Razif; } \\
\text { Singh, Manjinder; } \\
\text { Forde, Gareth M.; } \\
\text { Danquah, Michael } \\
\text { K. } \\
\end{array}$ & $\begin{array}{l}\text { RENEWABLE \& } \\
\text { SUSTAINABLE } \\
\text { ENERGY } \\
\text { REVIEWS }\end{array}$ & 2010 & 53 \\
\hline $\begin{array}{l}\text { Developments in } \\
\text { industrially important } \\
\text { thermostable enzymes: a } \\
\text { review }\end{array}$ & $\begin{array}{l}\text { Haki, GD; Rakshit, } \\
\text { SK }\end{array}$ & $\begin{array}{l}\text { BIORESOURCE } \\
\text { TECHNOLOGY }\end{array}$ & 2003 & 52 \\
\hline $\begin{array}{l}\text { Natural antioxidants and } \\
\text { antioxidant capacity of } \\
\text { Brassica vegetables: A } \\
\text { review }\end{array}$ & Podsedek, Anna & $\begin{array}{l}\text { LWT-FOOD } \\
\text { SCIENCE AND } \\
\text { TECHNOLOGY }\end{array}$ & 2007 & 52 \\
\hline
\end{tabular}




\begin{tabular}{|c|c|c|c|c|}
\hline $\begin{array}{l}\text { In vitro antioxidant } \\
\text { activities of methanol } \\
\text { extracts of five } \\
\text { Phyllanthus species from } \\
\text { India }\end{array}$ & $\begin{array}{l}\text { Kumaran, A.; } \\
\text { Karunakaran, R. } \\
\text { Joel }\end{array}$ & $\begin{array}{l}\text { LWT-FOOD } \\
\text { SCIENCE AND } \\
\text { TECHNOLOGY }\end{array}$ & 2007 & 51 \\
\hline $\begin{array}{l}\text { Milk-derived bioactive } \\
\text { peptides: From science } \\
\text { to applications }\end{array}$ & Korhonen, Hannu & \begin{tabular}{|l} 
JOURNAL OF \\
FUNCTIONAL \\
FOODS \\
\end{tabular} & 2009 & 51 \\
\hline $\begin{array}{l}\text { Antioxidant capacity, } \\
\text { vitamin C, phenolics, } \\
\text { and anthocyanins after } \\
\text { fresh storage of small } \\
\text { fruits }\end{array}$ & $\begin{array}{l}\text { Kalt, W; Forney, } \\
\text { CF; Martin, A; } \\
\text { Prior, RL }\end{array}$ & $\begin{array}{l}\text { JOURNAL OF } \\
\text { AGRICULTURAL } \\
\text { AND FOOD } \\
\text { CHEMISTRY }\end{array}$ & 1999 & 50 \\
\hline $\begin{array}{l}\text { Encapsulation of } \\
\text { polyphenols - a review }\end{array}$ & $\begin{array}{l}\text { Fang, Zhongxiang; } \\
\text { Bhandari, Bhesh }\end{array}$ & $\begin{array}{l}\text { TRENDS IN } \\
\text { FOOD SCIENCE } \\
\text { \& TECHNOLOGY } \\
\end{array}$ & 2010 & 50 \\
\hline $\begin{array}{l}\text { Emulsion-based delivery } \\
\text { systems for lipophilioc } \\
\text { bioactive components }\end{array}$ & $\begin{array}{l}\text { McClements, D. J.; } \\
\text { Decker, E. A.; } \\
\text { Weiss, J. } \\
\end{array}$ & $\begin{array}{l}\text { JOURNAL OF } \\
\text { FOOD SCIENCE }\end{array}$ & 2007 & 49 \\
\hline $\begin{array}{l}\text { Basic aspects of food } \\
\text { preservation by hurdle } \\
\text { technology }\end{array}$ & Leistner, L & $\begin{array}{l}\text { INTERNATIONA } \\
\text { L JOURNAL OF } \\
\text { FOOD } \\
\text { MICROBIOLOGY }\end{array}$ & 2000 & 48 \\
\hline $\begin{array}{l}\text { Encapsulation of } \\
\text { probiotic living cells: } \\
\text { From laboratory scale to } \\
\text { industrial applications }\end{array}$ & $\begin{array}{l}\text { Burgain, J.; Gaiani, } \\
\text { C.; Linder, M.; } \\
\text { Scher, J. }\end{array}$ & $\begin{array}{l}\text { JOURNAL OF } \\
\text { FOOD } \\
\text { ENGINEERING }\end{array}$ & 2011 & 48 \\
\hline $\begin{array}{l}\text { Evaluation of the ability } \\
\text { of antioxidants to } \\
\text { counteract lipid } \\
\text { oxidation: Existing } \\
\text { methods, new trends and } \\
\text { challenges }\end{array}$ & $\begin{array}{l}\text { Laguerre, M.; } \\
\text { Lecomte, J.; } \\
\text { Villeneuve, P. }\end{array}$ & $\begin{array}{l}\text { PROGRESS IN } \\
\text { LIPID } \\
\text { RESEARCH }\end{array}$ & 2007 & 47 \\
\hline $\begin{array}{l}\text { Effect of ultrasound on } \\
\text { the technological } \\
\text { properties and } \\
\text { bioactivity of food: a } \\
\text { review }\end{array}$ & $\begin{array}{l}\text { Soria, Ana } \\
\text { Cristina; Villamiel, } \\
\text { Mar }\end{array}$ & $\begin{array}{l}\text { TRENDS IN } \\
\text { FOOD SCIENCE } \\
\& \text { TECHNOLOGY }\end{array}$ & 2010 & 46 \\
\hline $\begin{array}{l}\text { Review of health safety } \\
\text { aspects of } \\
\text { nanotechnologies in } \\
\text { food production }\end{array}$ & $\begin{array}{l}\text { Bouwmeester, } \\
\text { Hans; Dekkers, } \\
\text { Susan; Noordam, } \\
\text { Maryvon Y.; } \\
\text { Hagens, Werner I.; } \\
\text { Bulder, Astrid S.; } \\
\text { de Heer, Cees; ten } \\
\text { Voorde, Sandra E. } \\
\text { C. G.; Wijnhoven, } \\
\text { Susan W. P.; } \\
\text { Marvin, Hans J. P.; } \\
\text { Sips, Adrienne J. }\end{array}$ & $\begin{array}{l}\text { REGULATORY } \\
\text { TOXICOLOGY } \\
\text { AND } \\
\text { PHARMACOLOG } \\
\text { Y }\end{array}$ & 2009 & 40 \\
\hline
\end{tabular}




\begin{tabular}{|c|c|c|c|c|}
\hline & A. M. & & & \\
\hline $\begin{array}{l}\text { Pressurized liquid } \\
\text { extraction as a green } \\
\text { approach in food and } \\
\text { herbal plants extraction: } \\
\text { A review }\end{array}$ & $\begin{array}{l}\text { Mustafa, Arwa; } \\
\text { Turner, Charlotta }\end{array}$ & $\begin{array}{l}\text { ANALYTICA } \\
\text { CHIMICA ACTA }\end{array}$ & 2011 & 45 \\
\hline $\begin{array}{l}\text { Food fermentations: role } \\
\text { of microorganisms in } \\
\text { food production and } \\
\text { preservation }\end{array}$ & $\begin{array}{l}\text { Caplice, E; } \\
\text { Fitzgerald, GF }\end{array}$ & $\begin{array}{l}\text { INTERNATIONA } \\
\text { L JOURNAL OF } \\
\text { FOOD } \\
\text { MICROBIOLOGY }\end{array}$ & 1999 & 44 \\
\hline $\begin{array}{l}\text { Recent advancements in } \\
\text { surface plasmon } \\
\text { resonance } \\
\text { immunosensors for } \\
\text { detection of small } \\
\text { molecules of biomedical, } \\
\text { food and environmental } \\
\text { interest }\end{array}$ & $\begin{array}{l}\text { Shankaran, } \\
\text { Dhesingh Ravi; } \\
\text { Gobi, K. Vengataj } \\
\text { Alabathy; Miura, } \\
\text { Norio }\end{array}$ & $\begin{array}{l}\text { SENSORS AND } \\
\text { ACTUATORS B- } \\
\text { CHEMICAL }\end{array}$ & 2007 & 44 \\
\hline $\begin{array}{l}\text { Mechanisms of lipid } \\
\text { oxidation in food } \\
\text { dispersions }\end{array}$ & $\begin{array}{l}\text { Waraho, Thaddao; } \\
\text { McClements, D. } \\
\text { Julian; Decker, } \\
\text { Eric A. }\end{array}$ & $\begin{array}{l}\text { TRENDS IN } \\
\text { FOOD SCIENCE } \\
\& \text { TECHNOLOGY }\end{array}$ & 2011 & 44 \\
\hline
\end{tabular}

